\title{
Commonness and Differences between
}

\section{Chinese and Western Market Economic Systems}

\author{
Anmin Chen \\ Institute of Economics \\ Shandong Economic University \\ Jinan 250014, China \\ E-mail: chenanminok@126.com
}

\begin{abstract}
The initially established market economic system in China has had several common features by comparison with those typical ones in western countries, and market mechanism has been a fundamental means for adjusting economic activities. However, in terms of ownership, scope of functioning in market subject and market mechanism, relations between government and enterprises, legal guarantee and moral constraints of market economy, the market economic system in China is still immature, and further reform is a necessary choice. Emphasis of the future reform lies in the following: to further perfect property right system, to improve macro-control policy, and to quicken political system reform so as to promote transition of government functions.
\end{abstract}

Keywords: China, Western countries, Market economic system

Market economy originated from western countries, and has been quite mature after its development and evolvement of almost a century, gradually accepted and adopted by many developing countries. To be specially mentioned, from the first socialist country in the early 1900s Soviet Russia, to other socialist countries founded after the Second World War in 1940s, all of them switched to the more efficient market economic system one by one after difficult exploration of planned economic system of almost a decade, which fully certified strong vitality of the market economy. Under such a circumstance, developing countries switching to market economy later, especially the transforming China, can't but carefully look into successful experiences and many disadvantages of western market economy, so as to learn from their strengths to make up for its weaknesses. Especially today when China has taken its first step in establishing the basic framework of market economic system and when is a key period for several aspects to be perfected, we should make more comprehensive and profound comparative analysis, in order to further absorb refined parts in those mature market economic systems, and to offer reference for successful progress of the key stage of the reform.

When analyzing and comparing the Chinese and western market economic systems, we could only regard the current (the beginning of the $21^{\text {st }}$ century) Chinese rudimental market economic system as a sample.

\section{In terms of ownership and market subject}

Western countries with the market economy all carry out private ownership of productive means. "Inviolability of private property" is the foundation for their building the country and the ground of their social system.

Of course, in different historical periods and in different countries, proportion of state-owned economy and private-owned economy respectively is different. In America, production value and employed population in state-owned enterprises was approximately $2 \%$. In Japanese, state-owned enterprises since the Second World War are mainly distributed in the fields of infrastructures, city public utilities, resource and energy exploitation, etc, and in fields of financing, insurance and medical treatment connected with social security causes, and their proportion are generally between 5\% and 10\%. In Germany, state-owned economy accounts for an important status in the country. Especially in such fields as infrastructure projects, post and telegraph, communications, railway, water supply and ports etc, state-owned economy occupies a proportion above 90\%. Among the Gross National Product, state-owned economy accounts for nearly $10 \%$. In addition to completely nationalized enterprises, there also exist some enterprises with a combination of public ownership and private ownership. Although similar to private enterprises in terms of 
management mechanism, large part of risks in these enterprises are assumed by the government since their government possesses its shares. In different countries, proportion of shareholding by the government is different. For instance, in Italy, proportion of shareholding by the country in large-sized enterprises attains above $50 \%$.

Generally speaking, although all countries have developed the state-owned economy to a certain extent after the Second World War, still private-owned economy occupies an absolutely dominant status among the total economic amount. This is the starting point and basis of western economic system. Private enterprises (mainly in the form of corporations, namely, the associated form of private capital) are distinctive in property and rights, and definite in responsibilities and rights, which supplies appropriate micro-subject for design and operation of all sorts of mechanisms in the market economy.

In the current China, through 30 years' advancement of reform in state-owned enterprises, most traditional state-owned enterprises have been transformed into corporate entity and market competition subject with independent management and sole responsibility. Since the reform and opening, China firstly enlarged self-operation of state-owned enterprises, then reformed their operation means (introducing several forms, such as contract and lease etc), which intensified their vigor. For resolution of contradictions at a deep level, China has advocated since 1993 that, establishment of a modern enterprise system with distinctive property and rights, definite rights and responsibilities, separate functions of government and enterprises, and scientific management is direction for reform of state-owned enterprises. Thereout, reform of state-owned enterprises has entered a stage of enterprise system innovation. So far, a modern enterprise system has been established at large among state-owned enterprises. Meanwhile, state-owned enterprises with a feature of grasping the large and neglecting the small have also achieved remarkable effects in their strategic reorganization, state-owned enterprises seceding and forwarding and some small-sized enterprises transformed into private-owned enterprises. Up to now, large-sized state-owned enterprises directly under the central government have been reduced to approximately 140 .

At the same time, according to the guideline of "the public ownership as the main form and the joint development of diversified forms of ownership", government at all levels has created for private-owned economy a policy environment and legal environment of fair competition, and has rapidly developed private enterprises. Due to natural profit chasing and flexibility of the mechanism among private enterprises, their economic benefits are generally better than those of state-owned enterprises.

The above state-owned enterprises and private-owned enterprises altogether constitute the micro-subject of Chinese market economy. Compared with western enterprises, they have both commonness with western enterprises and their own characteristics.

\subsection{Their commonness is mainly indicated in the following:}

1.1.1 Distinctive property and rights relations. An enterprise enjoys all the property rights of the legal person formed by investment of the investor (including the state, private individuals or other enterprises) of an enterprise, and becomes a corporate entity which enjoys civil rights and assumes civil responsibilities. Corporation, individually invested enterprise, and partnership are the primary organizational forms of enterprise property and rights.

1.1.2 Based on all of its corporate property, an enterprise, operates independently pursuant to the law, is responsible for its own profits or losses, pays taxes according to regulations, and assumes responsibility of value maintenance and appreciation for its investors.

1.1.3 Based on his invested capital, an investor enjoys interests of a proprietor.

1.1.4 According to market demands, an enterprise organizes its production and operation, with pursuit of profits as the direct target, and survives the market competition or is eliminated. Government has no direct intervene in production and operation of enterprises.

1.1.5 There exists a standardized governance structure within an enterprise, which is used to adjust and constrain relations of responsibility, rights and interests of proprietors, operators and employees.

\subsection{Differences between Chinese and western enterprises are mainly indicated in the following:}

1.2.1 Quantity and controlling force of their state-owned economy are six to one. As stated previously, state-owned economy in western countries merely account for less than $10 \%$ of the total national economy, and its impacts on the overall economy is relatively small. However, although quantity of state-owned enterprises and state-controlled enterprises in China has reduced from the original 238,000 to the current 150,000 approximately, their total assets have increased considerably. Among the significant industries and fields related to the national security and life of national economy, state-owned economy still occupies an absolute controlling force.

1.2.2 Enterprise reform in China, especially state-owned enterprise reform, is still not thorough. For example, constraint on property and rights in part of enterprises is not enough, a competence and motive of independent operation and self-innovation is lacking, extensive operation is relatively at large, and especially efficiency and benefits of 
state-owned enterprises still lag behind. However, enterprise system in western countries has been quite perfect, which is indicated in sound operation mechanism and sufficient operation independence. Therefore, for China, it is still extremely necessary to further deepen systems in state-owned enterprises, township enterprises, and collective enterprises. What's more, there still exist disadvantages in the structure of property and rights of some collective enterprises (whether in the city or in rural areas).

1.2.3 In terms of internal management system (or governance structure) of an enterprise, influences of political system result in great differences. Organizations of the Party are set up in most of internal enterprises (in addition to small-sized private enterprises) in China, which are responsible for supervising the carrying out and implementation of guidelines and policies of the Party and the nation. Although the Party organizations don't participate in daily operation of an enterprise, key issues are discussed and determined by the Party, especially when such issues related to human resource arrangement etc, are involved. Of course, the role of Party organizations may be more obvious in state-owned enterprises than that in private enterprises. In China, the primary function of corporate Labor Union and Employee Congress is to organize employees to participate in democratic management of the enterprise. However, this function has been weakened in the process of reform, let alone being strengthened, because this function endowed by the law is somewhat vacant, lacking in specific content and maneuverability. Meanwhile, the function of Labor Union negotiating with the investors on behalf of employees has not gained its deserved focus. As a specially established department within an enterprise, neither the membership nor the welfare of the professional Labor Union organizations and personnel is decided by employees, and their self-interests have no way to be in compliance with those of employees, so their helping employees to maintain their rights on behalf of them will not have a bright future. However, there doesn't exist any political organizations in western enterprises, and their operation and decision-making power in fastened on managerial personnel. The primary function of the Labor Union is to maintain interests of employees and to negotiate with investors on behalf of employees. Therefore, interests of employees in western enterprises can get more favorable protection.

\section{In terms of the role of market mechanism}

Through practices of reform and opening in the recent thirty years, there has formed a relatively complete market system with multi levels. At present, price of commodities and service is basically determined by the market. According to the statistics, among the total retail amount of social consumer goods, total takeover amount of agricultural products and total sale amount of production means, proportion of market regulation price respectively accounts for $95 \%, 96 \%$ and $87.8 \%$. Capital market has had its initial scope, and become enriched and perfect day by day. Primary land market has fundamentally taken the place of former planned supply system. Labor market has been expanded increasingly, and has stepped towards the target of consolidated rural-urban. Such intangible assets markets as technological market, and information consultation market have also been formed and been more and more standardized. All the above have reinforced the comprehensive regulating effect of market mechanism on economic activities within the national scope and in foreign economic cooperation. Market has become the primary means for distributing resources, and played a basic role. It is just in this sense that we say the market economic system has been basically established in China.

However, compared with perfect market system formed within almost a decade in western countries, the market system in China is still not perfect, which is mainly indicated in the following:

There exist defects in the pricing mechanism of some significant economic resources. For instance, price of land, energy and mining is still based on that predominated by government, and is not regulated by the market. When intervening price of these resources, the government is often influenced by several nonmarket factors (even non-economic factors), which causes incapability of the price of some products to exactly reflect their value and scarcity. For example, in recent years, the price of petroleum product deviates from the volatility of the international market. In addition, there exists the phenomenon of administrative monopoly in several industries, and their pricing mechanism is not perfect and transparent, which can't motivate managerial improvement and profit increasing in these enterprises. What's more, although each level of local government in China has played a positive role in organizing economic activities, they tend to become negative forces for the market mechanism due to their own interests (achievements, local fiscal revenue, benefits and welfare of officials, and even a desire for power rent-seeking). These negative forces might directly or indirectly result in regional blockade, market partition, repeated construction, and cut-throat competition (mainly manifested in terms of investment invitation, ne project launching, and image projects, etc). The result is that, some significant production resources and commodities can't flow freely to a larger extent, and therefore, the optimized distribution of production means can't be implemented.

\section{In terms of government intervene in economy and the relations between government and enterprises}

Modern market economy is no longer a laissez-faire market economy, since both Chinese and western market economy can't go without intervene and regulation by the government. Of course, in different countries, means and degree of economic intervene by the government differ largely, and differences between China and western countries are more obvious. 
In America, government intervene is mainly by means of policies of financing, revenue, and monetary policy, as well as government purchasing, eliminating the means of national plan. The country has no annual or medium-and-long-term development plan. Specific investment, production and operation activities are completely and independently decided by the enterprise. Similar to America, Britain is known as the typical market economy nation. Japan and France are known as nations with a planned and market economic system. Japanese government attaches great importance to the use of medium-and-long-term plan to intervene macroscopic economy. Economic plan and industrial policy are two distinctive means used by Japanese government to introduce enterprise investment and make operational decisions, which had positive effect in the economic growth after the Second World War. Besides, Japan also pays great attention to regulating means, such as financial policy, and monetary policy, etc. However, Japanese governmental intervene in the economy gives priority to economic and indirect means, without direct administrative command or compulsory plan. And France is noted for its instructive economic plan. The first task for the French plan is to set up a constructive target, and then achieve this target through coordination of enterprises, the nation and all levels of economic departments. This plan has coordinated interests of all economic subjects, and has created a relatively harmonious economic environment. Meanwhile, the government makes use of public budget and demonstrative driving role of state-owned enterprises to realize economic development target. German is known as a social market economic system nation. Its primary characteristics include three aspects: firstly, to promote efficiency, to ensure that market mechanism will play a basic role in resource distribution, to tap enthusiasm of humans and to realize economic development and prosperity through market competition; secondly, to pursue and establish a system of fair competition. For this, the government has constituted policies and laws to maintain free competition; thirdly, to pursue realization of social fairness. It emphasizes that unfairness in distribution should be overcome through governmental intervene, and emphasizes that interests of all the people should be protected, not of particular interest groups. Thereby, the government strives to construct a social guarantee network (negating those nations implementing welfare). Economic policies to realize the previous targets by the government mainly include monopoly restraint, monetary stabilization, sufficient employment, and guarantee of balance of international balance of payments.

In China, although the government doesn't run enterprises directly, it still holds two identities concurrently, namely, the subject of macro-economic management and the subject of national ownership. To deal with the relationships between these two, an essential method is to separate politics from capital, and to separate the function of state-owned capital by the government to be taken charge of by special institutions (or authorized investors), while the government provides special service in the market economy. And the government should play a role of "macro-regulator" and "economic policeman". Due to incomplete reform, transition of governmental function lags behind reform of other systems, which leads to the coexistence of "Offside and "Omission". On one hand, there still exists the situation when the government intervenes the micro-economic behaviors, which causes the result that, some behaviors of an enterprise deviates from market signal, value rule and maximal principle of profits. On the other hand, the phenomenon of omission is serious in public service function of the government, which results in unfair market competition, infestation of various potential rules, extremely imperfect social guarantee and some significant and inextricable livelihood issues of citizens. Unfair social distribution phenomena spread all over, legal rights and interests of city-and-rural laborers can't get guaranteed, and social credit system is not sound, etc,. All the above indicates that, political system reform should go hand in hand with that of economic system, and transition of governmental functions has to shoulder heavy responsibilities none the less.

Macro-regulation function of the government in China exceeds that in western countries. The task of macro-regulation is to maintain basic balance of total economic gross, to promote optimization of economic structure, and to lead sustainable, rapid and healthy development of economy. Its primary means include financial and revenue policy, financing and monetary policy, investment policy, and planned management. The current plan is generally instructive, and plays a guiding role with the market as the basis, which mainly provides service in macro-economic target and industrial policy. There still exist some disadvantages in macro-regulation issues for Chinese government, which are mainly indicated in the following: target of macro-regulation over-focuses on ensuring economic growth, especially growth of GDP, which is caused by unilateral performance concept; alternating emergence of frequent alteration of regulating policy and its lagging; competition of interests between the central government and local results in unsuccessful implementation of policies, and therefore emerges the phenomenon of Policy, under countermeasures (such as the real estate market regulation policy); redundant examining and approval systems have become a "forcing house" for the phenomena of power rent-seeking and corruption.

\section{In terms of standardized degree of market economic system}

The market economic system with its initial shape is still not perfect in China, and several game rules are still open to be standardized and perfected, which lies in two aspects:

\subsection{Legal economic system is still not perfect}

Since the reform and opening, achievements of the legal system establishment in China has been striking. So far, most 
fields of economic activities have had a law to abide by, but legislative task is still rather tough. On one hand, laws are lacking in some fields, and are out-dated in other fields, therefore needed to be updated and perfected. On the other hand, some laws are short of systematization, even mutually contradictory, some laws are lacking in maneuverability, too general, and some laws are in defect of corresponding regulations and implementation rules. Particularly, with the daily development of information technology and fantasticality of the financial market, new legal rules are in great need for regulating. In the fields of social guarantee and income distribution, and in terms of planning rural-and-city economic and social development, construction of legal systems still lags behind.

\subsection{Economic orders are open to be standardized}

Social credit system is not sound, with imperfect credit service system, and punishment for faith breaking has just been established. There exists administrative monopoly in a large number of industries and economic fields, lacking in an open, fair and equitable market competition order. Construction of economic and ethic morality is weak. And furthermore, in the situation when the traditional ideology and political education gradually loses its effect, no more effective means has been found to improve the ethic morality quality of economic activity participants. Under the impelling of a strong desire of getting enriched, commercial bribe gets popularized. Potential rules everywhere has largely counteracted regulating role of apparent rules (namely, laws and policies), which results in distorted economic behaviors in enterprises, individuals and the government. From the perspective of the entire society, the result not only impairs impartiality, but also blocks efficiency.

However, market rules and legal systems formed for a long period of time in western market economic countries are more mature and perfect. Of course, there also exist lots of issues in these countries. For instance, supervision of the government on the financial market and capital market is weak, and virtual economy is over-developed, etc, which, likewise, need being reformed and perfected, and require a continually optimized market.

\section{References}

Ma, Kai. (2006). To Unswervingly Deepen Reforms, Carry out Scientific Approach to Development, and to Construct the System Guarantee of a Harmonious Society. Economic Daily News, April $5^{\text {th }}$.

Zhou, Zhaoguang. (2002). Comparison and Countermeasures of Market Economic System. Anxui University Press, 25. 